\section{Mapping music education research in Brazil and Argentina: the British impact}

\author{
LIANE HENTSCHKE \\ FEDERAL UNIVERSITY OF RIO GRANDE DO SUL - UFRGS, BRAZIL \\ ISABEL MARTÍNEZ \\ UNIVERSIDAD NACIONAL DE LA PLATA, ARGENTINA
}

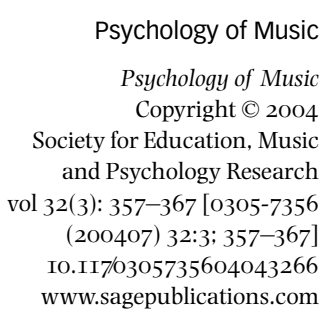

Psychology of Music

Psychology of Music Copyright (c) 2004 Society for Education, Music and Psychology Research vol 32(3): 357-367 [0305-7356 (200407) 32:3; 357-367] I0.II7/0305735604043266 www.sagepublications.com

\author{
UNIVBRIDAD NACIONAL DE LA pLATA, a
}

\begin{abstract}
In this brief article we share with our colleagues around the world the British impact on the development of music education and psychology of music research in Brazil and Argentina. Although both countries are pursuing similar research policies, their research areas differ. Brazilian research on music education has had its focus on curriculum studies, evaluation, psychology of music, and media studies. Argentina on the other hand has a strong tradition in research in music education and psychology of music, in particular developmental and cognitive aspects of music perception and performance. Both countries are working towards the improvement of music research in South America and the continuation of the fertile partnership with British scholars and institutions.
\end{abstract}

KEYWORDS: Britain, research, South America

The articles presented in this special issue of Psychology of Music reveal the extent of the research developed in the UK and an indication of how it has served as a reference to the development of research in other parts of the world, including Brazil and Argentina. In this brief article we would like to share with our colleagues, internationally, the impact British researchers and scholars have had over the years in the development of music education and psychology of music research, in both countries. First, we will review what each country is engaged with and second, present a joint perspective of the future of research in this part of the world.

\title{
Brazil
}

Research in music education in Brazil is a fairly new enterprise. It started in the late 1980s when the first music educators returned to Brazil with their 
PhDs obtained in universities in the USA, UK, Germany and France. Soon we had a community of researchers that helped to create graduate programmes in music and music education and also the Brazilian Society for Music Education - ABEM. Both initiatives played an important political and academic role in developing music education in Brazil.

Music education in Brazil has been influenced by many countries, especially those where Brazilian music educators received their MAs and PhDs. However, the influence of British researchers has been the most prominent, especially in the last decade. Among the works developed by British scholars (Keith Swanwick (1979, 1988, 1994, 1999); John Paynter (1982; with Aston 1970); John Sloboda (1985); David Hargreaves (1986; with North 1999); John Blacking (1987); Lucy Green (1988, 1997, 2001); Charles Plummeridge, (1991); Janet Mills (1993, 1998); Gordon Cox (1999)), the one that generated the most research was the work of Keith Swanwick.

A series of research projects into music assessment have been developed following the work by Hentschke (1993). These were set up to investigate if responses made through audience-listening could be mapped according to the Swanwick (1988) criteria of musical development. Among these is the work of Del Ben (1997) and Cunha (1998) with Brazilian children, which generated an extension of the audience-listening criteria proposed by Swanwick (1988). The work of Grossi (1999) was also related to audiencelistening assessment, where she investigated the dimensions of musical responses in order to broaden the scope of musical experience in listening tests, especially in the context of Brazilian higher education music courses. On the performance side, the work of Santos (1998) and Tourinho (2000) relate to Swanwick's (1994) assessment criteria for performance, researching how music teachers assess the performance of their students. The latest work, developed by Andrade (2001), investigated the implicit criteria used by conductors to assess their choirs.

In terms of curriculum development, Hentschke and Oliveira (1999) carried out a longitudinal study based on Swanwick's Theory of Musical Development. The aim of the project was to investigate the possibility of using Swanwick's theory as a theoretical framework to develop and evaluate a music curriculum proposal for primary schools. This project was created based on existing evidence that the Theory of Musical Development and model could be used to assess children's musical products through composing, performing and listening (Swanwick and Tillman, 1986; Swanwick, 1988, 1994; Hentschke, 1993; Del Ben, 1997; Silva, 1998; Hentschke and Del Ben, 1999; Swanwick and França, 1999). Another study which discusses the possibility of working with composition, performance and audiencelistening in schools is that of Swanwick and França (1999). Studying the musical work of 20 children in a music school in Belo Horizonte, Brazil, and taking the assessment criteria of Swanwick and Tillman (1986) and Swanwick (1988), the authors suggest that performance usually elicits lower 
levels of musical understanding, significantly different from either composing or audience-listening, supporting the need for an integrated music curriculum. Recent research by Salgado (2000) stressed the importance of the use of composition as a regular practice in music studies, particularly in conservatories and higher education, as opposed to a model that considers composition as an isolated discipline in the curriculum.

Related to the development of software and new technologies, we have the work of Krüger (1996, 2000), Krüger et al. (1999), and Ficheman et al. (2002). They are developing a website and composition software for children based on a virtual collaborative learning environment. This work has been strongly influenced by the music education concepts set out in Swanwick $(1988,1999)$ and by other British scholars related to technology in education, such as Squires and McDougall (1994).

Brazil has a long tradition of informal music practice, but only recently have Brazilian music educators started to investigate a set of issues related to informal music learning. The work of Lucy Green $(1997,2001)$ has been very influential, in research related to popular music learning (Hentschke et al., 2002). Her latest book (Green, 2001) has inspired the setting up of a collaborative research project between the Federal University of Bahia and the Federal University of Rio Grande do Sul (Hentschke et al., 1999). This research was developed in two Brazilian states (Bahia and Rio Grande do Sul) in order to investigate informal music learning processes in adolescents in rock bands (Hentschke et al., 2002). Preliminary results have shown that the processes used by Brazilian adolescents to learn music are very similar to the ones used by popular musicians and adolescents in the UK and USA (Campbell, 1995; Green, 2001).

The research projects described above have been influential in the sense of offering Brazilian music educators a theoretical and practical perspective that can be used to enhance musical practices in Brazilian schools. Although the Brazilian social and cultural scenario differs from the British one, the research developed over the last ten years has revealed that it is possible to share theoretical and practical frameworks that mutually enhance our music education research and practices.

\section{Argentina}

Music education has a long tradition in Argentina. Music has been a curricular subject in schools since the beginning of the 20th century. Specialized music teachers are in charge of music classes from the kindergarten to the secondary school. During the last 50 years, Argentina was influenced by European and American traditions in music pedagogy and educational psychology. Pedagogic approaches developed by European music educators, such as E.J. Dalcroze and E. Willems, among others, consistently affected local musical practices. Compositional techniques applied to activities in 
school contexts, that were developed by contemporary music composers, such as John Paynter, are familiar in Argentine schools. At present, the works of Keith Swanwick and David Hargreaves, among others, are esteemed in undergraduate courses of teacher education.

During the 1970s, US advances in music education, together with highlights of general educational, developmental and experimental psychology, shaped the local music education environment. The main British and US journals of music education were frequently points of reference, and some Argentine music educators visited regularly the international conferences organized by the International Society for Music Education (ISME). An interesting Argentine community of music scholars grew and produced a number of seminal pedagogical books and materials. At present, music teachers find in these sources the main guidelines for the practice of music in schools. Thus, it is to be expected that a number of interesting research questions about music behaviour, music teaching and learning arose within this context.

However, it was not until the late 1980s, and more intensely during the 1990s, that systematic music research began in Argentina. Higher education in arts and social sciences traditionally emphasized the undergraduate level; therefore, artistic rather than research production was encouraged. In 1994, changes carried out in the National Education System, triggered the promulgation of both Federal Education and Higher Education Laws, and incorporated postgraduate studies as a priority. This generated a rescheduling in higher education, and scientific research emerged in areas that had been historically overlooked. The first national higher education research programme was designed, and thus music research was allocated for the first time at the university. A group of music scholars, interested in music behaviour, music analysis and music theory, explored the field of the psychology of music. Since then, there have been influences from a range of diverse research traditions. However, specific mention is made here of the influences of British researchers, especially in the last decade.

The main contribution involves the particular way in which British scholars have approached research in music education, often with strong foundations in the psychology of music. The first points of reference were John Sloboda's book The Musical Mind (1985) and the journal Psychology of Music. During the 1990s, an intense exchange between Argentine and British academics started, including visits by Graham Welch and John Sloboda. In between, Argentine scholars visited some of the main British research centres in psychology of music and music education and, afterwards, they began doctoral level studies, still ongoing, in the UK. A number of research papers were submitted to the most important international conferences in music perception and cognition (such as International Conference in Music Perception and Cognition (ICMPC)) and music education (such as ISME).

At a local level, scientific meetings were organized regularly with the 
purpose of developing further scientific and academic links with South American- and Spanish-speaking research communities. Special and personal efforts were made to maintain regular subscriptions to the most important research journals in the field. The first scientific society focused on music and science, SACCoM (Argentine Society for the Cognitive Sciences of Music) was created in 2001. The aims of the society are to:

- encourage research into the psychology of music in the local environment, according to international research standards;

- incorporate local research activity within the international research community; and

- look for financial sources to support research in the field.

Thus, the pioneering work of former Argentine music education societies (SADEM; FEM) was enhanced, emphasizing the idea that the basics of music behaviour must be framed by strong evidence derived from the findings in the field of the psychology of music.

Finally, a specialized field was set up at university level. Its contents are included in the programmes of music courses. In 1998, a postgraduate course in Psychology of Music was designed, with the initial supervision of British researchers. In 2003, a Masters in Psychology of Music began at the Universidad Nacional de La Plata for the first time in Argentina. At present, a growing community of researchers is seeking to understand more clearly the cognitive, biological and social foundations of music behaviour and experience. What follows is a selection of recent developments in Argentine music research with foundations in the psychology of music that, nevertheless, is not intended to be exhaustive. This agenda includes research related to the following topics:

1. Music development: In terms of musical understanding there is research on concept acquisition and categorization in the field of musical sound (Furnó, 2000, 2002; Furnó et al., 2002). Recent studies have focused on the cognition of hierarchic structure, looking for evidence of its acquisition (Martínez and Shifres, 1999a; Shifres and Martínez, 2002). In terms of rhythm and temporal organization, there is research on the development of rhythmic synchrony (Malbrán 2001, 2002a, 2002b).

2. Music cognition: Some endeavours have focused on the representation of tonal structure, investigating the listener's sensitivity to surface and prolongational features in different cognitive tasks, among them, similarity judgements (Martínez and Shifres, 1999b; Martínez, 2000; Martínez and Shifres, 2000) and attention to music (Martínez, 2001a, 2002).

3. Music performance: Concerning expressive performance, there is a series of studies devoted to investigating the performer's representation of the underlying structure (Shifres and Martínez, 2000b) and the communication of structural components in expert performance (Shifres, 2001a, 
2001b, 2001c; Shifres and Martínez, 2000a). There is also research on parametric analysis of singing skills, using physiological measurements (Mauléon, 2000; Mauléon and Gurlekian, 2001). Sight-reading of polyphonic music is currently being investigated (Sánchez, 2001) and the representation of metric structure in sight-reading has also been studied (Saavedra and Deluchi, 2000).

4. Music perception and performance in teaching and learning educational contexts: Several studies on singing skills have been run with kindergarten and primary school children (Monaco, 2001). There have been recent experiments aimed at testing generative learning skills, such as the aural identification of harmonic progressions in the context of ear training courses (Martínez et al., 1999) and the transcription of melodic fragments (Martínez, 1997). There are also promising studies relating to the cognitive foundations of the education of the professional musician (Musumeci, 20012002).

5. Music education and social practices: Studies on reception activities have focused on style preferences (Cano De Guelar et al., 2000).

The research projects referred to above provide an account of the current and potential perspectives of research in music education and the psychology of music and offer a fruitful source for future inquiry. At the same time, they address a number of important issues, the study of which is essential if the aim is to enrich Argentine music education research and influence practice in schools, conservatoires and universities.

\section{Future challenges}

Two features of this current context present challenges to research in this field: the postgraduate system and financial support. In Brazil, graduate programmes in music are well established, although research funding is not always available. In Argentina, on the other hand, programmes and financial support are currently in an embryonic developmental state, their vulnerability having been increased because of the current economic crisis. Given that both Brazil and Argentina are pursuing similar research policies it is expected that the reinforcement of academic and financial exchange will help the enhancement of music research in South America and will also strengthen the already fertile partnership with British scholars and institutions.

REFERENCES

Andrade, M.A. (2001) Avaliação em Execução Musical: Estudo sobre Critérios Utilizados por Regentes de Grupos Corais Escolares, unpublished Master of Education dissertation. Curitiba: Universidade Federal do Paraná.

Blacking, J. (1987) 'A Commonsense View of all Music': Reflections on Percy Grainger's Contribution to Ethnomusicology and Music Education. Cambridge: Cambridge University Press. 
Campbell, P.S. (1995) 'Of Garage Bands and Song-Setting: The Musical Development of Young Rock Musicians', Research Studies in Music Education 4: 12-20.

Cano De Guelar, T., Aguilar, M., Rodriguez Moran, I. and Sánchez, B. (2000) 'Audición Musical: Preferencias Estilísticas de Alumnos de 8vo Año de la EGB', in S. Malbrán and F. Shifres (eds) III Conferencia Iberoamericana de Investigación Musical, pp. 23-32. Mar del Plata, Argentina: FEM.

Cox, G. (1999) 'Secondary School Music Teachers Talking', Music Education Research 1(1): 37-47.

Cunha, E.S. (1998) Apreciação Musical: Uma Análise Comparativa entre Dois Métodos De Avaliação, unpublished master's dissertation, postgraduate music programme, Instituto de Artes. Porto Alegre: Universidade Federal do Rio Grande do Sul.

Del Ben, L.M. (1997) A Utilização do Modelo Espiral de Desenvolvimento Musical Como Critério de Avaliação Da Apreciação Musical em um Contexto Educacional Brasileiro, unpublished master's dissertation, postgraduate music programme, Instituto de Artes. Porto Alegre: Universidade Federal do Rio Grande do Sul.

Ficheman, I.K., Lopes, R.D. and Krüger, S.E. (2002) 'A Virtual Collaborative Learning Environment', in Anais do SIACG 2002 - 1st Ibero-American Symposium on Computer Graphics, pp. 75-82. Guimarães, Portugal: Simpósio Ibero-Americano de Computação Gráfica.

Furnó, S. (2000) 'Concepts and Categorization in the Field of Musical Sound. TAS: Test of Sound Attributes', in C. Woods, G. Luck, R. Brochard, F. Seddon and J.A. Sloboda (eds) Proceedings of the Sixth International Conference on Music Perception and Cognition (CD-ROM). Keele: University of Keele.

Furnó, S. (2002) 'Formación de Conceptos en el Campo del Sonido Musical', unpublished $\mathrm{PhD}$ thesis, Universidad Nacional de La Plata, Faculty of Humanities and Educational Sciences.

Furnó, S., Valles, M. and Burcet, M.I. (2002) ‘Criterios Categoriales en la Formación de Conceptos Referidos al Sonido Musical', in I. Martinez and O. Musumeci (eds) Actas de la Segunda Reunión Anual de SACCoM (CD-ROM). Buenos Aires: SACCoM.

Green, L. (1988) Music on Deaf Ears: Musical Meaning, Ideology and Education. Manchester and New York: Manchester University Press.

Green, L. (1997) Music, Gender, Education. Cambridge: Cambridge University Press.

Green, L. (2001) How Popular Musicians Learn: A Way Ahead For Music Education. London and New York: Ashgate.

Grossi, C. (1999) 'Assessing Musical Listening: Musical Perspectives of Tertiary Students and Contemporary Brazilian Composers', unpublished PhD thesis, Institute of Education, University of London.

Hargreaves, D.J. (1986) The Developmental Psychology of Music. Cambridge: Cambridge University Press.

Hargreaves, D.J. and North, A.C. (1999) 'Developing Concepts of Musical Style', Musicae Scientiae 3: 193-216.

Hentschke, L. (1993) 'Musical Development: Testing a Model in Audience-Listening Setting', unpublished $\mathrm{PhD}$ thesis, Insitute of Education, University of London.

Hentschke, L. and Del Ben, L.M. (1999) 'The Assessment of Audience-Listening: Testing a Model in the Educational Setting of Brazil', Music Education Research (1) 2: 127-46.

Hentschke, L. and Oliveira, A.J. (1999) 'Music Curriculum Development and Evaluation Based on Swanwick's Theory', International Journal of Music Education 34: 14-29.

Hentschke, L., Cunha, E., Souza, J. and Bozzetto, A. (2002) 'Bandas de Rock: Qual 
Repertório? Como Tocar? - Um Estudo Multi-casos com Adolescentes', in L. Hentschke (ed.) Anais do XI Encontro Anual da ABEM, pp. 385-91. Belém: ABEM.

Hentschke, L., Souza, J. and Oliveira, A. (1999) 'Articulações de Processos Pedagógicos Musicais em Ambientes Escolares e Não Escolares: Estudos Multicasos em Porto Alegre, RS e Salvador, BA', research project sponsored by CNPq and FAPERGS.

Krüger, S.E. (1996) Análise de Softwares de Educação Musical quanto à sua Compatibilidade ao Ensino do Piano: Monografia de Especialização em Educação Musical. Curitiba: Escola de Música e Belas Artes do Paraná.

Krüger, S.E. (2000) Desenvolvimento, Testagem e Proposta de um Roteiro para Avaliação de Software para Educação Musical, unpublished master's dissertation, postgraduate music programme, Instituto de Artes. Porto Alegre: Universidade Federal do Rio Grande do Sul.

Krüger, S.E., Gerling, C.C. and Hentschke, L. (1999) 'A Utilizacao de Software no Processo de Ensino e Aprendizagem de Instrumentals de Teclado', Edição eletrônica da Revista OPUS Vol. 6. Rio de Janeiro: ANPPOM [http://www.musica.ufmg.br/anppom/opus/opus6/kruger.htm].

Malbrán, S. (2001) 'Phases in Children's Rhythmic Development', in R. Zatorre and I. Peretz (eds) The Biological Foundations of Music. Annals of the New York Academy of Science Vol. 930. New York: New York Academy of Science.

Malbrán, S. (2002a) 'Tapping in Time: A Longitudinal Study at the Age of Three to Five Years', in G. Welch and Goran Folkestad (eds) Bulletin of the Council for Music Education 153(4): 71-7. Special issue published by SEMPRE.

Malbrán, S. (2002b) 'La Sincronía Rítmica como Forma Particular de la Organización Temporal', unpublished PhD thesis, Faculty of Humanities and Educational Sciences, Universidad Nacional de La Plata.

Martínez, I. (1997) 'The Transcription of Pitches in Tonal Melodies. A Comparative Study', in Alf Gabrielsson (ed.) Proceedings of the Third ESCOM Conference, pp. 269-74. Uppsala, Sweden: University of Uppsala.

Martínez, I. (2000) 'La Asimetría al Juzgar la Similitud Perceptiva de Melodías', in S. Malbrán and F. Shifres (eds) III Conferencia Iberoamericana de Investigación Musical, 85-8. Mar del Plata, Argentina: FEM.

Martínez, I. (2001a) 'The Use of Prolongation in Music Attending', in W.F. Thompson (ed.) Abstracts of the SMPC 2001, pp. 53-4. Ontario: Queen University.

Martínez, I. (2001b) 'Prolongation as a Structural Constituent in Music Attending', in, F. Shifres (ed.) Actas de la Primera Reunión Anual de SACCoM (CD-ROM). Buenos Aires: SACCoM.

Martínez, I. (2002) 'Prolongation and Music Attending: A Click Localization Study', in C. Stevens, D. Burnham, G. McPherson, E. Schubert and J. Renwick (eds) Proceedings of the 7th International Conference on Music Perception and Cognition (CD-ROM), pp. 633-6. Causal Productions: Sydney.

Martínez, I. and Shifres, F. (1999a) 'Music Education and the Development of Structural Hearing: A Study with Children', in M. Barrett, G. McPherson and R. Smith (eds) Children and Music: Developmental Perspectives, pp. 184-90. Proceedings of the Second International Musical Education Research Symposium. Tasmania: UNIPRINT, University of Tasmania.

Martínez, I. and Shifres, F. (1999b) 'The Rivalry Between Structure and Surface While Judging the Similarity of Melodies', in R. Ashley (ed.) Abstracts of the SMPCC99, p. 28. Evanston, IL: Northwestern University. 
Martínez, I. and Shifres, F. (2000) 'Testing Models as Predictors of the Rivalry Between Structure and Surface in the Perception of Melodies', in C. Woods, G. Luck, R. Prochard, F. Seddon and J.A. Sloboda (eds) Proceedings of the Sixth International Conference on Music Perception and Cognition (CD ROM). Keele: University of Keele.

Martínez, I., Malbrán, S. and Shifres, F. (1999) 'The Role of Repetition in Aural Identification of Harmonic Sequences', Bulletin of the Council for Research in Music Education 141: 93-7.

Mauléon, C. (2000) 'El Canto con y Sin Apoyo. Aportes y Limitaciones de la Tecnología', in S. Malbrán and F. Shifres (eds) III Conferencia Iberoamericana de Investigación Musical, pp. 89-92. Mar del Plata, Argentina: FEM.

Mauléon, C. and Gurlekian, J. (2001) ‘Consonantes Oclusivas Sordas en el Canto: Un Estudio Sobre la /T/', In F. Shifres (ed.) Actas de la Primera Reunión Anual de SACCoM (CD-ROM). Buenos Aires: SACCoM.

Mills, J. (1993) Music in the Primary School, 2nd edition, revised for the original National Curriculum. Cambridge: Cambridge University Press.

Mills, J. (1998) 'Music', in G. Clay, J. Hertrich, P. Jones, J. Mills and J. Rose The Arts Inspected. London: Heinemann/OfSTED.

Mónaco, M. (2001) 'La Tesitura Espontánea en Niños de Tres y Cuatro Años', in F. Shifres (ed.) Actas de la Primera Reunión Anual de SACCoM (CD-ROM). Buenos Aires: SACCoM.

Musumeci, O. (2001) 'Diferentes Niveles de Logro en Hermanos que Tocan un Mismo Instrumento: Un Estudio de Casos en un Conservatorio', in F. Shifres (ed.) Actas de la Primera Reunión Anual de SACCoM (CD-ROM). Buenos Aires: SACCoM.

Musumeci, O. (2002) 'Hacia Una Educación de Conservatorio Humanamente Compatible', in I. Martinez and O. Musumeci (eds) Actas de la Segunda Reunión Anual de SACCoM (CD-ROM). Buenos Aires: SACCoM.

Paynter, J. (1982) Music in the Secondary School Curriculum: Trends and Developments in Class Music Teaching. Cambridge: Cambridge University Press.

Paynter, J. and Aston, P. (1970) Sound and Silence: Classroom Projects in Creative Music. Cambridge: Cambridge University Press.

Plummeridge, C. (1991) Music Education in Theory and Practice. Basingstoke: Burgess Science Press.

Saavedra, M.P. and Deluchi, P.C. (2000) 'Denominador de la Cifra de Compás Binario y Lectura a Primera Vista: Avances de un Estudio con Músicos de Orquesta', in J. Tafuri (ed.) La riccerca per la Didattica musicale. Atti del convegno SIEM, 263-9. Bologna: SIEM.

Salgado, J.A. (2000) 'Composition as a Tool for Music Studies in Higher Education and Conservatories', unpublished MA dissertation, Institute of Education, University of London.

Sánchez, B. (2001) 'Exámen del Texto Musical. Movimiento Ocular e Identificación del Contenido', in F. Shifres (ed.) Actas de la Primera Reunión Anual de SACCoM (CD-ROM). Buenos Aires: SACCoM.

Santos, C.G.A. (1998) A Avaliação da Execução Musical: Um Estudo sobre os Critérios Utilizados por Professores de Piano, unpublished master's dissertation, postgraduate music programme, Instituto de Artes. Porto Alegre: Universidade Federal do Rio Grande do Sul.

Shifres, F. (2001a) 'El Ejecutante como Intérprete: Un Estudio Acerca de la Cooperación Interpretativa del Ejecutante en la Obra Musical', in F. Shifres (ed.) Actas de la Primera Reunión Anual de SACCoM (CD-ROM). Buenos Aires: SACCoM. 
Shifres, F. (2001b) 'The Communication of Voice Leading from an Interpreter Perspective', in W.F. Thompson (ed.) Abstracts of the SMPC 2001, p. 67. Ontario: Queen University.

Shifres, F. (2001c) 'Ejecución Musical, Comunicación y Estructura Profunda', in S. Furnó and M. Arturi (eds) Actas del ENIAD (CD-ROM). Universidad Nacional de La Plata.

Shifres, F. and Martínez, I. (2000a) 'The Role of Performance in the Cognitive Reality of the Hierarchic Structure', in C. Woods, G. Luck, R. Prochard, F. Seddon, and J.A. Sloboda (eds) Proceedings of the Sixth International Conference on Music Perception and Cognition (CD ROM). Keele: University of Keele.

Shifres, F. and Martínez, I. (2000b) 'Examinando el Rol de la Ejecución en la Cognición de la Estructura Musical Jerárquica.Un Estudio Basado En Tareas De Estimación', in S. Malbrán and F. Shifres (eds) III Conferencia Iberoamericana de Investigación Musical, pp. 118-22. Mar del Plata, Argentina: FEM.

Shifres, F. and Martínez, I. (2002) 'The Acquisition of Prolongation as a Structural Constituent in Music Attending', in C. Stevens, D. Burnham, G. McPherson, E. Schubert and J. Renwick (eds) Proceedings of the 7 th International conference on Music Perception and Cognition (CD-ROM), p. 637. Sydney. Australia.

Silva, C.C.F. (1998) 'Composing, Performing and Audience Listening as Symmetrical Indicators of Musical Understanding', unpublished $\mathrm{PhD}$ thesis, Institute of Education, University of London.

Sloboda, J.A. (1985) The Musical Mind: The Cognitive Psychology of Music. Oxford: Clarendon Press.

Squires, D. and Mcdougall, A. (1994) Choosing and Using Educational Software: A Teachers' Guide. London: Falmer Press.

Swanwick, K. (1979) A Basis for Music Education. Windsor: NFER/Nelson.

Swanwick, K. (1988) Music Mind and Education. London: Routledge.

Swanwick, K. (1994) Musical Knowledge: Intuition, Analysis and Music Education. London: Routledge.

Swanwick, K. (1999) Teaching Music Musically. London: Routledge.

Swanwick, K. and França, C.C. (1999) 'Composing, Performing and AudienceListening as Indicators of Musical Understanding', British Journal of Music Education 16(1): 5-19.

Swanwick, K. and Tillman J. (1986) 'The Sequence of Musical Development: A Study of Children's Composition', British Journal of Music Education 3(3): 305-40.

Tourinho, C. (2001) Relações entre os Critérios de Avaliação do Professor de Violão e uma Teoria de Desenvolvimento Musical: Tese de Doutorado, unpublished $\mathrm{PhD}$ thesis, postgraduate music programme - Escola de Música. Salvador: Universidade Federal da Bahia.

Liane hentschke is Professor of Music Education and Deputy Director of the Graduate Programme in Music in the Institute of Arts at the Universidade Federal do Rio Grande do Sul, Brazil. She works at the undergraduate and graduate level, supervising MA and PhD students. Liane's publications include books, book chapters, and journal articles published in Brazil, the UK, Argentina and Spain. For six years she has worked as an advisor for music at the Brazilian Ministry of Education. She was a member of the Board of Directors of ISME for four years and a member of the Executive Committee for two years. She is currently Co-editor of the ISME journal, Internal Journal of Music Education: Practice. 
Address: Music Department, Federal University of Rio Grande do Sul - UFRGS, Porto Alegre-RS-Brazil. [email: hentschk@portoweb.com.br]

ISABEL MARTínez is Music Researcher and Professor of Ear Training and Teacher Training at the Faculty of Fine Arts in the Universidad Nacional de La Plata. She is a past president of the Argentine Society for the Cognitive Sciences of Music (SACCoM). She is currently a doctorate student at the University of Roehampton, Surrey, UK. She has been consultant at the National Education Authority in the area of Music and Artistic Education. Her current research interests concern the field of Music Perception and Cognition with a focus on the listeners' mental representation of tonal structure. In the last few years she has submitted papers to the main conferences in the field.

Address: Facultad de Bellas Artes, Universidad Nacional de La Plata, 58 no 1409 (1900) La Plata- Buenos Aires, Argentina. [email: icm@isis.unlp.edu.ar] 